\title{
ANALISIS POTENSI DAN EFEKTIVITAS PENERIMAAN DAN PEMUNGUTAN PAJAK MINERAL BUKAN LOGAM DAN BATUAN SEBAGAI SUMBER PENDAPATAN ASLI DAERAH (PAD) DI KABUPATEN MINAHASA UTARA
}

\author{
Moningka Tesalonika ${ }^{1}$ \\ Agus T. Poputra ${ }^{2}$ \\ Lidia Mawikere ${ }^{3}$ \\ Fakultas Ekonomi dan Bisnis, Jurusan Akuntansi \\ Universitas Sam Ratulangi Manado \\ email: tesamoningka@gmail.com
}

\begin{abstract}
Taxes are the country's largest source of financing in national development. This study purposed to analyze the potential and effectiveness of Non Metallic Minerals and rocks tax, as a source of regional revenue in North Minahasa District. The analytical method used is descriptive qualitative method, using primary data and secondary data. The results showed that the potential tax increases every year, the level of effectiveness of the Metallic Minerals Tax and rocks in 2012 - 2015 meet the criteria for highly effective, the highest level of effectiveness achieved in 2013 with a percentage of $111 \%$ to the target and the realization of very large. In 2015 the tax revenue Metallic Minerals and Rocks that most large compared with previous years. Improved performance of the employees to optimize each of the duties and responsibilities in the process of collecting that tax revenue Metallic Minerals and rocks can be more effective in the future.
\end{abstract}

Keyword :mineral tax, local revenue, potential and effectiveness

\section{PENDAHULUAN}

\section{Latar Belakang}

Pembangunan nasional adalah kegiatan yang berlangsung secara terus-menerus dan berkesinambungan.Pembangunan tersebut bertujuan untuk mencerdaskan kehidupan bangsa dan kesejahteraan rakyat Indonesia secara adil, makmur dan merata.Pemerintah sebagai dinamisator dan stabilisator tentunya melakukan pungutan pajak bukan tanpa alasan, yang pasti semua itu mempunyai tujuan.Tujuan itulah yang mendasarkan bahwa membayar pajak itu wajib untuk warga negara Indonesia.Dengan adanya pajak, bukan tidak mungkin Indonesia mampu berkembang baik karena kita tahu bahwa selama ini Indonesia mampu bertahan dan berkembang karena pajak yang berpengaruh besar terhadap negara ini (Noviantari, 2014).Pada tahun 1999 telah ditetapkan pembagian pajak menurut wewenang pemungutan pajak dipisahkan menjadi Pajak Pusat dan Pajak Daerah. Menurut UU Nomor 28 Tahun 2009 tentang Pajak Daerah dan Retribusi Daerah, pemerintah daerah diberikan kewenangan seluas luasnya untuk mengelola asset daerahnya dalam merinci dan memungut pendapatan bagi daerahnya sendiri (Lazio, 2012).

Pajak daerah adalah pajak yang dipungut pemerintah daerah dan digunakan untuk membiayai rumah tangga daerah (Mardiasmo, 2011 : 1).Pemerintah daerah harus mengetahui kondisi dan potensi daerahnya dalam pemenuhan pembiayaan pembangunan di daerah.Jenis-jenis pajak daerah bagian Kabupatan/Kota terdiri atas, pajak hotel, pajak restoran, pajak hiburan, pajak reklame, pajak penerangan jalan, pajak mineral bukan logam dan batuan, pajak air tanah, pajak sarang burung wallet, pajak bumi dan bangunan perdesaan dan perkotaan, bea perolehan hak atas tanah dan bangunan, dan pajak parker (Fitriandi, et al., 2011). Pajak Daerah merupakan salah satu sektor penerimaan PAD (Damang, 2011). Komponen pajak daerah yang perlu mendapatkan perhatian lebih oleh pemerintah Kabupaten Minahasa Utara adalah Pajak Mineral Bukan Logam dan Batuan seiring meningkatnya kebutuhan akan bahan mineral bukan logam dan batuan yang digunakan sebagai bahan dasar industri dan pembangunan pemukiman di kawasan Kabupaten Minahasa Utara. 
Potensi bahan mineral bukan logam dan batuan adalah kekuatan yang ada disuatu daerah untuk menghasilkan penerimaan Pajak Mineral Bukan Logam dan Batuan. Dengan mengetahui lebih dalam dari seberapa efektif Pajak Pengambilan dan Pengolahan Mineral Bukan Logam dan Batuan Kabupaten Minahasa Utara, diharapkan mampu mengoptimalkan penerimaan Pajak Pengambilan dan Pengolahan Mineral Bukan Logam dan Batuan sehingga dapat meningkatkan kontribusi terhadap pendapatan daerah.Kondisi Kabupaten Minahasa Utara yang sementara berkembang dengan penduduk yang mulai padat serta memiliki kegiatan ekonomi yang tinggi, memungkinkan adanya wajib pajak yang tidak tepat waktu bahkan tidak membayar pajak sama sekali.Efektivitas pemungutan pajak menggambarkan kinerja suatu pemerintahan.Analisis efektivitas mutlak diperlukan guna mengukur sejauh mana pelaksanaan pemungutan Pajak Pengambilan dan Pengolahan Mineral Bukan Logam dan Batuan di Kabupaten Minahasa Utara.

\section{Tujuan Penelitian}

Tujuan penelitian ini adalah untuk mengetahui bagaimana potensi dan efektivitas penerimaan dan pemungutan pajak mineral bukan logam dan batuan sebagai sumber pendapatan asli daerah di Kabupaten Minahasa Utara.

\section{Konsep Akuntansi}

\section{TINJAUAN PUSTAKA}

Kieso (2011:5) menyatakan akuntansi sebagai bahasa universal dari bisnis.Karakteristik penting dari akuntansi adalah identifikasi, pengukuran, dan komunikasi informasi keuangan tentang entitas ekonomi kepada pihak yang berkepentingan.Akuntansi adalah proses identifikasi, pencatatan dan komunikasi terhadap transaksi ekonomi dari suatu entitas/perusahaan (Wibowo, 2011). Definisi American Institude of Certified Public Accounting (AICPA) akuntansi merupakan suatu seni pencatatan, penggolongan dan pengikhtisaran dengan cara tertentu dan dalam ukuran moneter transaksi dan kejadian yang umumnya bersifat keuangan dan mentafsir hasil-hasilnya.

\section{Konsep Perpajakan}

Pajak merupakan salah satu perwujudan dan kewajiban kenegaraan yang merupakan sarana peran serta masyarakat dalam pembiayaan negara dan pembangunan nasional (Susilo, 2014).Menurut Waluyo (2013:3) pajak adalah iuran wajib berupa uang atau barang yang dipungut oleh penguasa berdasarkan norma-norma hukum, guna menutup biaya produksi barang-barang dan jasa-jasa kolektif dalam mencapai kesejahteraan umum.

\section{Fungsi Pajak}

Fungsi pajak menurut Resmi (2011:3) adalah sebagai berikut.

1. Fungsi Budgetair yaitu pajak merupakan salah satu penerimaan pemerintah untuk membiaya pengeluaran baik rutin maupun pembangunan.

2. Fungsi Mengatur (Regulerend) yaitu Pajak mempunyai fungsi mengatur, artinya pajak sebagai alat untuk mengatur atau melaksanakan kebijakan pemerintah dalam bidang sosial dan ekonomi.

\section{Jenis Pajak}

Undang-Undang No. 28 Tahun 2009 tentang Pajak Daerah dan Retribusi Daerah membedakan 2 jenis Pajak Daerah, yaitu Pajak Provinsi dan Pajak Kabupaten/Kota. 1. Jenis Pajak Provinsi terdiri atas:
a. Pajak Kendaraan Bermotor
b. Bea Balik Nama Kendaraan Bermotor
c. Pajak Bahan Bakar Kendaraan Bermotor 
d. Pajak Air Permukaan, dan

e. Pajak Rokok

2. Adapun jenis Pajak Kabupaten/kota terdiri atas :

a. Pajak Hotel

b. Pajak Retoran

c. Pajak Hiburan

d. Pajak Reklame

e. Pajak Penerangan Jalan

f. Pajak Mineral Bukan Logam dan Batuan

g. Pajak Parkir

h. Pajak Air Tanah

i. Pajak Sarang Burung Walet

j. Pajak Bumi dan Bangunan Pedesaan dan Perkotaan, serta

k. Bea Perolehan Hak atas Tanah dan Bangunan.

\section{Tata Cara Pemungutan Pajak}

Pemungutan pajak dapat dilakukan dengan tiga cara, yaitu sebagai berikut.

1. Stelsel Pajak

2. Asas Pemungutan

3. Sistem Pemungutan Pajak

\section{Pajak Mineral Bukan Logam dan Batuan}

UU No. 28 tahun 2009 Pasal 1 menyatakan bahwa Pajak Mineral Bukan Logam dan Batuan adalah pajak atas kegiatan pengambilan mineral bukan logam dan batuan, baik dari sumber alam di dalam dan/atau permukaan bumi untuk dimanfaatkan

\section{Subjek dan Objek Pajak Mineral Bukan Logam dan Batuan}

Subjek Pajak Mineral Bukan Logam dan Batuan adalah orang pribadi atau Badan yang dapat mengambil Mineral Bukan Logam dan Batuan.Untuk objek pajak adalah kegiatan eksploitasi bahan mineral bukan logam dan batuan, yang terdiri atas esbes, tall, mike, grafit, magnesit, batu tulis, marmer, Batu kapur, Dolomit, kalsit, Bentonit, Foldspar, Batu gamping, Pasir, Pasir kwarsa, tanah liat, trakkit, basal, andesit, Phospate, nitrat, garam batu, batu apung, teras, absidian, perlit dan tanah diatome.

\section{Tarif Pajak Mineral Bukan Logam dan Batuan}

UU No. 28 tahun 2009 Pasal 60 menyatakan bahwa, Tarif Pajak Mineral Bukan Logam dan Batuan ditetapkan paling tinggi sebesar 25\% (dua puluh lima persen).Sesuai PERDA di Kabupaten Minahasa Utara, tarif pajak mineral bukan logam dan batuan ditetapkan sebesar 20\%.

\section{PotensiPenerimaan Pajak Mineral Bukan Logam dan Batuan}

Potensi merupakan sesuatu yang sebenarnya sudah ada, hanya belum didapat atau diperoleh di tangan.Potensi pajak mineral bukan logam dan batuan diartikan sebagai kekuatan sebenarnya dari pajak mineral bukan logam dan batuan. Analisis perhitungan potensi diperlukan dalam menentukan target secara rasional.

\section{Efektivitas Pemuungutan Pajak Mineral Bukan Logam dan Batuan}

Secara umum efektivitas menunjukkan seberapa jauh tercapainya suatu tujuan yang terlebih dahulu ditentukan. Efektivitas menggambarkan kemampuan pemerintah daerah dalam merealisasikan pendapatan yang direncanakan dibandingkan dengan target yang ditetapkan (Halim, 2011: 128).Efektivitas yaitu hubungan antara output dan tujuan atau dapat juga dikatakan merupakan ukuran seberapa jauh tingkat output tertentu, kebijakan dan prosedur dari organisasi. 


\section{Pendapatan Asli Daerah}

Pendapatan daerah adalah semua hak daerah yang diakui sebagai penambah nilai kekayaan bersih dalam periode anggaran tertentu (UU.No 32 Tahun 2004 tentang pemerintahan daerah), pendapatan daerah berasal dari penerimaan dari dana perimbangan pusat dan daerah, juga yang berasal daerah itu sendiri yaitu PAD serta lain-lain pendapatan yang sah.

\section{Sumber-Sumber Pendapatan Asli Daerah}

UU No. 28 Tahun 2009, sumber-sumber Pendapatan Asli Daerah terdiri atas:

1. Hasil Pajak Daerah

2. Hasil Retribusi Daerah

3. Hasil Pengelolaan Kekayaan Daerah yang Dipisahkan

4. Lain-Lain Pendapatan Asli Daerah Yang Sah.

\section{Penelitian Terdahulu}

Iktama (2013) dalam penelitian berjudul Analisis Potensi dan Efektivitas Pemungutan Pajak Mineral Bukan Logam dan Batuan di Kabupaten Tuban, tujuan dari penelitian ini adalah untuk mengetahui potensi penerimaan Pajak Mineral Bukan Logam dan Batuan, mengetahui efektivitas pemungutan Pajak Mineral bukan Logam dan Batuan selama selama tahun 2006 - 2010, dan mengetahui strategi terbaik yang harus dilakukan agar mendapatkan hasil yang optimal dalam penerimaan Pajak Mineral bukan Logam dan Batuan. Metode penelitian menggunakan metode kualitatif.Dari hasil perhitungan potensi penerimaan Pajak Mineral Bukan Logam dan Batuan Kabupaten Tuban tahun anggaran 2006 - 2010 berdasarkan target penerimaan mencapai 108,31 persen atau dengan kata lain sangat efektif.

Rahmawati (2014) dalam penelitian yang berjudul Analisis Potensi Penerimaan Pajak Mineral Bukan Logam dan Batuan Sebagai Sumber Pendapatan Asli Daerah di Kabupaten Gresik.Tujuan dalam penelitian ini adalah bagaimana potensi penerimaan Pajak Mineral Bukan Logam dan Batuan sebagai sumber Pendapatan Asli Daerah (PAD) di Kabupaten Gresik, Bagaimana tingkat efektivitas penerimaan Pajak Mineral Bukan Logam dan Batuan di Kabupaten Gresik, Bagaimana strategi terbaik yang harus dilakukan oleh Pemerintah Kabupaten Gresik untuk mengoptimalkan penerimaan Pajak Mineral Bukan Logam dan Batuan sebagai sumber Pendapatan Asli Daerah (PAD). Metode penelitiannya yaitu deskriptif kuantitatif. Hasil penelitiannya yaitu Efektivitas pajak mineral bukan logam dan batuan Kabupaten Gresik tahun 2009-2013 berdasarkan target penerimaan rata-rata sangat efektif. Sedangkan efektivitas pajak mineral bukan logam dan batuan berdasarkan potensi penerimaan menunjukkan kurang efektif kecuali di tahun 2013 sangat efektif. Dalam penetapan target pajak mineral bukan logam dan batuan, DPPKAD hanya mengacu pada realisasi tahun sebelumnya tidak sesuai dengan potensi yang ada sehingga tingkat efektivitas pajak mineral bukan logam dan batuan berdasarkan potensi penerimaan menunjukkan kurang efektif

\section{Jenis Penelitian}

\section{METODE PENELITIAN}

Jenis penelitian yang digunakan adalah pendekatan deskriptif kualitatif.Pendekatan deskriptif kualitatif yaitu suatu prosedur penelitian yang menggunakan data deskriptif berupa kata-kata tertulis atau lisan dari orang-orang dan pelaku yang dapat diamati (Sugiyono, 2011).Dalam penelitian ini, peneliti hanya terbatas pada perhitungan besaran potensi dan prosentase efektivitas yang di dapat dari data kuantitatif yang berkaitan dengan penerimaan Pajak Pengambilan dan Pengolahan Bahan Galian Mineral bukan Logam dan Batuan di Kabupaten Minahasa Utara.

\section{Tempat dan Waktu Penelitian}

Dalam penelitian tempat atau lokasi penelitian sangat penting untuk mengetahui letak yang sebenarnya.Penelitian ini dilakukan pada Dinas Pendapatan Daerah Kabupaten Minahasa Utara. Adapun waktu penelitian ini diawali pada bulan maret 2016. 


\section{Metode Pengumpulan Data}

Jenis data yang digunakan pada penelitian ini yaitu deskriptif kualitatif.Data secara umum merupakan kumpulan dari fakta yang diperoleh dari penelitian. Data yang diolah akan menghasilkan sesuatu hal baru, bisa merupakan konsep, atau kejadian tertentu. Melakukan wawancara kepada pihak Dinas Pendapatan Daerah Kabupaten Minahasa Utara dalam pencapaian realisasi penerimaan pajak dari target yang ditetapkan juga mengadakan pencatatan terhadap dokumen-dokumen dan data-data lain yang dapat menunjang..

\section{Metode Analisis}

Metode analisa data yang digunakan dalam penelitian ini adalah analisa deskriptif kualitatif.Adapun langkah-langkah pengolahan data adalah sebagai berikut.

1. Pengukuran Potensi Pajak Mineral Bukan Logam dan Batuan

Menurut (Ratu, 2010) pengukuran potensi pajak Mineral Bukan Logam dan Batuan atau Pajak Pengambilan Bahan Galian Golongan C secara matematis dapat dirumuskan sebagai berikut.

\footnotetext{
dimana

Pt : Potensi penerimaan Pajak mineral bukan logam dan batuan

: Penjumlahan potensi dari obyek pajak ke 1 sampai ke $\mathrm{n}$ mineral bukan logam dan batuan

VI : Volume mineral bukan logam dan batuan yang dieksploitasi dalam $\mathrm{m} 3 /$ tahun.

Hrg: Harga standar dari jenis mineral bukan logam dan batuan yang telah ditetapkan Rp/m3

Tr : Besarnya tarif pajak (20\%)
}

2. Pengukuran Efektivitas Pemungutan Pajak Mineral Bukan Logam dan Batuan Rumus pengukuran efektivitas untuk pemungutan pajak adalah sebagai berikut.

\section{Efektivitas $=$}

Dengan kriteria sebagai berikut.

Tabel 1 Tabel Interpretasi Nilai Efektivitas

\begin{tabular}{cc}
\hline Persentase Kriteria & \\
\hline$>100 \%$ & Sangat Efektif \\
$90-100 \%$ & Efektif \\
$80-90 \%$ & Cukup Efektif \\
$60-80 \%$ & Kurang Efektif \\
$<60 \%$ & Tidak Efektif \\
\hline Depdagri, Kepmendagri No.690.900.327 (Halim, 2011)
\end{tabular}

\section{HASIL PENELITIAN DAN PEMBAHASAN}

\section{Hasil Penelitian}

\section{Potensi Penerimaan Pajak Mineral Bukan Logam dan Batuan}

Potensi pajak mineral bukan logam dan batuan diartikan sebagai kekuatan sebenarnya dari pajak mineral bukan logam dan batuan. Analisis perhitungan potensi diperlukan dalam menentukan target secara rasional. 
Dalam melakukan perhitungan besaran potensi pajak mineral bukan logam dan batuan, diperlukan data jenis objek pajak mineral bukan logam dan batuan, kapasitas/tonase/volume eksploitasi bahan mineral bukan logam dan batuan, harga pasar masing-masing bahan mineral bukan logam dan batuan, dan tarif pajak masing-masing bahan mineral bukan logam dan batuan yang diambil dari tahun 2011-2015.

Tabel 2Perhitungan Potensi Penerimaan Pajak Mineral Bukan Logam dan Batuan Tahun 2011-2015

\begin{tabular}{|c|c|c|c|c|c|}
\hline Tahun & Jenis Bahan Galian & $\begin{array}{c}\text { Volume } \\
\text { Produksi } \\
\left(\mathrm{m}^{3}\right) / \text { Tahun }\end{array}$ & $\begin{array}{c}\text { Harga } \\
\text { Standar } \\
\left(\mathrm{Rp} / \mathrm{m}^{3}\right)\end{array}$ & $\begin{array}{l}\text { Tarif } \\
\text { Pajak }\end{array}$ & $\begin{array}{l}\text { Potensi Pajak } \\
\text { (Rp) }\end{array}$ \\
\hline \multirow[t]{4}{*}{2011} & Batu Pecah $(2-3 \mathrm{~cm})$ & 2480,68 & 150.000 & $20 \%$ & 74.420 .400 \\
\hline & $(1-2 \mathrm{~cm})$ & 2730,88 & 170.000 & $20 \%$ & 92.849 .920 \\
\hline & Batu dan Sirtu & 19523,45 & 50.000 & $20 \%$ & 195.234 .500 \\
\hline & Pasir & 39520 & 35.000 & $20 \%$ & 276.640 .000 \\
\hline \multicolumn{5}{|c|}{ Jumlah } & 639.144 .820 \\
\hline \multirow[t]{3}{*}{2012} & Batu Pecah $(1-2 \mathrm{~cm})$ & 3372,87 & 170.000 & $20 \%$ & 114.677 .580 \\
\hline & Batu dan sirtu & 21290.12 & 50.000 & $20 \%$ & 212.901 .200 \\
\hline & Pasir & 39492,76 & 35.000 & $20 \%$ & 276.444 .000 \\
\hline \multicolumn{5}{|c|}{ Jumlah } & 604.022 .780 \\
\hline \multirow[t]{2}{*}{2013} & Pasir & 58132,85 & 35.000 & $20 \%$ & 406.929 .950 \\
\hline & Batu Gunung dan Batu Kal & 48251 & 50.000 & $20 \%$ & 482.510 .000 \\
\hline \multicolumn{5}{|c|}{ Jumlah } & 889.439 .950 \\
\hline \multirow[t]{4}{*}{2014} & Pasir & 47506,12 & 35.000 & $20 \%$ & 332.542 .840 \\
\hline & Batu dasar & 23980 & 50.000 & $20 \%$ & 239.800 .000 \\
\hline & Batu pecah $(1-2 \mathrm{~cm})$ & 4879,23 & 170.000 & $20 \%$ & 165.893 .820 \\
\hline & Tanah urug & 58201 & 30.000 & $20 \%$ & 349.206 .000 \\
\hline \multicolumn{4}{|c|}{ Jumlah } & & 1.087 .442 .660 \\
\hline \multirow[t]{9}{*}{2015} & Pasir & 50127,20 & 35.000 & $20 \%$ & 350.890 .400 \\
\hline & Batu pecah $(0-0,5 \mathrm{~cm})$ & 2765,32 & 150.000 & $20 \%$ & 82.959 .600 \\
\hline & $(0,5-1 \mathrm{~cm})$ & 4520 & 195.000 & $20 \%$ & 176.280 .000 \\
\hline & $(1-2 \mathrm{~cm})$ & 3250 & 170.000 & $20 \%$ & 110.500 .000 \\
\hline & $(2-3 \mathrm{~cm})$ & 3655,52 & 150.000 & $20 \%$ & 109.665 .600 \\
\hline & $(3-5 \mathrm{~cm})$ & 6268,33 & 120.000 & $20 \%$ & 150.439 .920 \\
\hline & $(5-7 \mathrm{~cm})$ & 3982.59 & 100.000 & $20 \%$ & 79.651 .800 \\
\hline & \multicolumn{2}{|c|}{ Jumlah } & & & 1.060 .387 .320 \\
\hline & \multicolumn{3}{|c|}{ Jumlah Total } & & 4.280 .437 .530 \\
\hline
\end{tabular}

Sumber : Dinas Energi Sumber Daya Mineral Kabupaten Minahasa Utara

Hasil perhitungan potensi penerimaan pajak mineral bukan logam dan batuan tahun 2011 sampai dengan tahun 2015 dengan total sebesar Rp.4.280.437.530.

Tabel 3 Persentase Kenaikan Jumlah Potensi Tiap Tahun

\begin{tabular}{cccc}
\hline \multirow{2}{*}{ Tahun } & Jumlah Potensi & \multicolumn{2}{c}{ Kenaikan } \\
\cline { 3 - 4 } & & Jumlah & Persentase \\
\hline 2011 & 639.144 .820 & -35.122 .040 & $-5.4 \%$ \\
\hline 2012 & 604.022 .780 & 285.417 .170 & $47.2 \%$ \\
\hline 2013 & 889.439 .950 & 196.002 .710 & $22 \%$ \\
\hline 2014 & 1.087 .442 .660 & -27.055 .340 & $-2.4 \%$ \\
\hline 2015 & 1.060 .387 .320 & & $15.35 \%$ \\
\hline
\end{tabular}

Sumber : Data Olahan 


\section{Perkembangan Pendapatan Asli Derah (PAD) Kabupaten Minahasa Utara}

Kabupaten Minahasa Utara merupakan salah satu Kabupaten di Provinsi Sulawesi Utara yang memiliki Penghasilan Asli Daerah (PAD) yang baik dan potensial dibandingkan dengan daerahdaerah lain di provinsi ini.

Tabel 4 Perkembangan Pendapatan Asli Daerah Kabupaten Minahasa Utara Tahun Anggaran 2011-2015

\begin{tabular}{ccccr}
\hline No & $\begin{array}{c}\text { PAD } \\
\text { (Tahun) }\end{array}$ & $\begin{array}{c}\text { Target } \\
(\mathbf{R p})\end{array}$ & $\begin{array}{c}\text { Realisasi } \\
(\mathbf{R p})\end{array}$ & $\begin{array}{c}\text { Prosentase } \\
\text { \% }\end{array}$ \\
\hline 1. & 2011 & 10.602 .131 .490 & 13.186 .468 .031 & 124,38 \\
2. & 2012 & 15.217 .348 .565 & 20.623643 .750 & 135,53 \\
3. & 2013 & 22.095 .143 .551 & 20.315 .322 .560 & 91,94 \\
4. & 2014 & 18.025 .000 .000 & 20.070 .096 .061 & 113,35 \\
5. & 2015 & 22.295 .000 .000 & 25.266 .469 .042 & 110,21 \\
\hline \multicolumn{4}{c}{}
\end{tabular}

Dapat dilihat bahwa PAD Kabupaten Minahasa Utara dari tahun 2011 sampai tahun 2015 mengalami peningkatan yang cukup baik, meskipun pada tahun 2013 mengalami penurunan yang tidak terlalu jauh. Tahun 2015 merupakan pendapatan tertinggi, yaitu sebesar 25.266.469.042. Prosentase kenaikan dari tahun ketahun mencapai 115,082 \%. Ini tentunya untuk mendukung pengembangan daerah khususnya Kabupaten Minahasa Utara. Sebagaimana dipaparkan pada bagian sebelumnya bahwa pembangunan memerlukan pembiayaan.

\section{Efektivitas Pemungutan Pajak Mineral Bukan Logam dan Batuan}

Efektivitas Pajak Bahan Galian Mineral bukan Logam dan Batuan di Kabupaten Minahasa Utara dalam lima tahun terakhir atau dari tahun 2011 sampai 2015 mengalami perkembangan yang cukup baik itu dapat dilihat dalam Tabel 5 berikut ini.

\section{Tabel 5 Perkembangan Efektivitas Pemungutan Pajak Bahan Galian Mineral Bukan} Logam dan Batuan Tahun 2011-2015

\begin{tabular}{cccccrc}
\hline No & $\begin{array}{c}\text { Tahun } \\
\text { Anggaran }\end{array}$ & $\begin{array}{l}\text { Target } \\
(\mathbf{R p})\end{array}$ & $\begin{array}{c}\text { Realisasi } \\
(\mathbf{R p})\end{array}$ & $\begin{array}{c}\text { Selisih } \\
(\mathbf{R p})\end{array}$ & $\begin{array}{c}\text { Prosentase } \\
\text { Efektivitas }\end{array}$ & $\begin{array}{c}\text { Kriteria } \\
\text { Efektivitas }\end{array}$ \\
\hline 1. & 2011 & 650.000 .000 & 589.494 .778 & 60.505 .222 & $91 \%$ & Efektif \\
2. & 2012 & 650.000 .000 & 668.198 .270 & 18.198 .270 & $103 \%$ & Sangat Efektif \\
3. & 2013 & 677.158 .000 & 752.919 .608 & 75.761 .608 & $111 \%$ & Sangat Efektif \\
4. & 2014 & 1.000 .000 .000 & 1.088 .776 .090 & 88.776 .090 & $109 \%$ & Sangat Efektif \\
5. & 2015 & 1.000 .000 .000 & 1.018 .062 .400 & 18.062 .400 & $102 \%$ & Sangat Efektif \\
\hline
\end{tabular}

Sumber:Dinas Pendapatan Daerah Kabupaten Minahasa Utara

Pada tahun 2011 total penerimaan pajak bahan galian mineral bukan logam dan batuan mengalami penurunan yaitu $\mathrm{Rp} 589.494 .778$, sedangkan target yang diharapkan pemerintah daerah adalah sebesar $\mathrm{Rp} 650.000 .000$, target yang diharapkan pemerintah cukup besar karena semakin banyak tempat usaha dalam pertambangan batu bata, batu kali, batako, kerikil, pasir plester maupun tanah urung yang berada di hampir 10 kecamatan di Kabupaten Minahasa Utara. Dapat dilihat juga bahwa tahun 2015, yang merupakan tahun terakhir penelitian memperlihatkan realisasi penerimaan pajak melebihi target. Target tahun 2015 sebesar Rp. 1.000.000.000,-. Sedangkan realisasi Rp. 1.018.062.400. Prosentase kenaikan sebesar $102 \%$.Pada tahun 2013 mendapatkan prosentase yang tertinggi yaitu sebesar $111 \%$. Target tahun 2013 sebesar Rp. 677.158.000,- sedangkan realisasinya sebesar Rp. 752.919.608,- 


\section{Pembahasan}

Dari hasil penelitian dapat diketahui bahwa penerimaan Pajak Bahan Galian Mineral bukan Logam dan Batuan di Kabupaten Minahasa Utara tahun 2011 sampai tahun 2015 terus mengalami peningkatan.Kabupaten Minahasa Utara memiliki koefisien efektivitas rata-rata sebesar 103,2\% atau lebih dari $100 \%$, jadi tingkat efektif pajak bahan galian bukan logam dan batuan di Kabupaten Minahasa Utara menurut standarisasi efektivitas atau kriteria efektivitas yang ada dinyatakan sangat efektif untuk penerimaan atau pengambilan pajak dan pengolahan pajak tersebut.

Dari hasil identifikasi dan pemetaan yang dilakukan akan dapat dijadikan bahan untuk menetapkan target penerimaan dan pemungutan pajak pengambilan bahan galian mineral bukan logam dan batuan. Sehingga target penerimaan dan pemungutan pajak pengambilan bahan galian mineral bukan logam dan batuan akan lebih proposional dan memiliki kemungkinan untuk bisa direalisasikan.Instansi pelaksana pemungutan pajak pengambilan bahan galian mineral bukan logam dan batuan, dalam hal ini Dinas Pendapatan Daerah Kabupaten Minahasa Utarasudah cukup mampu dalam melaksanakan visi dan misi yang diembankan, cukup mampu menyesuaikan diri dengan lingkungannya dan cukup memiliki pengalaman dalam pemungutan pajak di tambang-tambang bahan galian mineral bukan logam dan batuan.Langkah berikutnya komitmen yang dimiliki oleh petugas harus sama, sehingga memiliki keinginan untuk bisa merealisasikan tujuan atau target penerimaan pajak mineral bukan logam dan batuan dengan maksimal dan efektif.

\section{Kesimpulan}

\section{PENUTUP}

Kesimpulan dari penelitian ini adalah:

1. Dari hasil perhitungan potensi penerimaan pajak mineral bukan logam dan batuan Kabupaten Minahasa Utara tahun 2011-2015 terlihat bahwa potensi pajak mineral bukan logam dan batuan terus mengalami kenaikan di tiap tahunnya. Dengan perhitungan potensi penerimaan Pajak Mineral Bukan Logam dan Batuan Kabupaten Minahasa Utara tahun anggaran 2011 - 2015 menunjukkan hasil sebesar Rp. 4.280.437.530,-. Dengan persentase rata-rata kenaikan sebesar $15.35 \%$.

2. Tingkat efektivitas pemungutan pajak mineral bukan logam dan batuan sebagai sumber pendapatan asli daerah di Kabupaten Minahasa Utara pada tahun 2011 - 2015 dikatakan sangat efektif dengan persentase lebih dari $100 \%$.

\section{Saran}

Saran dalam penelitian ini adalah:

1. Penyuluhan yang lebih intensif dan persuasif kepada Wajib Pajak khususnya dan masyarakat pada umumnya. Langkah berikutnya adalah memberikan sanksi tegas kepada Wajib Pajak yang tidak memenuhi kewajiban perpajakan sebagaimana mestinya.

2. Perlu diadakannya modernisasi seperti pengorganisasian fungsi serta tugas di pihak Dinas Pendapatan Daerah Kabupaten Minahasa Utara untuk menghindari penumpukkan pekerjaan serta kekuasaan baik dari segi fasilitas maupun sistem dasarnya agar memudahkan proses pemungutan pajak.

3. Memperhatikan kompensasi yang lebih memadai kepada para petugas sehingga mereka dapat termotivasi untuk mengoptimalkan setiap tugas dan tanggung jawabnya. Peningkatan kinerja para pegawai di lingkungan instansi ini pun perlu dilakukan dengan mengikuti berbagai pelatihanpelatihan teknis yang relevan.

\section{DAFTAR PUSTAKA}

Andrew Susilo, 2014. Peran Pajak bagi Pembangunan Negara

Damang, 2011."Pendapatan Asli Daerah" Hukum tata Negara.

Fitriandi Primandita, Aryanto Yuda, Priyanto Agus Puji. 2011. Kompilasi Undang-Undang

Perpajakan Terlengkap, Salemba Empat, Jakarta.

Halim, Abdul. 2011. Akuntansi Sektor Publik-Akuntansi Keuangan Daerah. Jakarta: Salemba Empat. 
Iktama, Siska. 2012. Analisis Potensi dan Efektivitas Pemungutan Pajak Mineral Bukan Logam dan Batuan di Kabupaten Tuban (Skripsi). Universitas Brawijaya.

Kieso, Weygandt, Jerry J, Donald E.2011. Accounting Principles.Edisi 7. Salemba Empat, Jakarta

Lazio, Sonny. 2012. Pengertian dan Sumber-Sumber Pendapatan Asli Daerah.

Mardiasmo. 2011. Perpajakan Edisi Revisi, Andi, Yogyakarta.

Rahmawati Indah ,2014. Analisis potensi penerimaan pajak mineral bukan logam dan batuan sebagai sumber pendapatan asli daerah kabupaten gresik.

Ratu, Andi. Nurdi Brasit dan Jusni.2010. Strategi Peningkatan Kontribusi Usaha Pertambangan

Terhadap Pendapatan Asli Daerah (PAD) Kota Palopo.Jurnal, (Online), (pascaunhas.ac.id/jurnal/)

Resmi, siti.2011. Perpajakan Teori dan Kasus.Edisi 4. Salemba Empat, Jakarta.

Sugiyono. 2011. Metodologi Penelitian Kombinasi, Jakarta.

Tia Dwi Noviantari, 2014. Peran Pajak Dalam Perekonomian di Indonesia.

Waluyo. 2013. Perpajakan Indonesia, Salemba Empat, Jakarta.

Wibowo. 2011. Akuntansi Untuk Bisnis dan Usaha Menengah, Jakarta 